\title{
Centenarians in India: the present scenario
}

\section{Kallol Kumar Bhattacharyya*}

\author{
Imambara Sadar Hospital, Chinsurah, Hooghly, West Bengal, India
}

Received: 02 May 2017

Revised: 27 May 2017

Accepted: 29 May 2017

\section{*Correspondence:}

Dr. Kallol Kumar Bhattacharyya,

E-mail: dearkkb@ rediffmail.com

Copyright: (C) the author(s), publisher and licensee Medip Academy. This is an open-access article distributed under the terms of the Creative Commons Attribution Non-Commercial License, which permits unrestricted non-commercial use, distribution, and reproduction in any medium, provided the original work is properly cited.

\begin{abstract}
India, officially the Republic of India is a country in South Asia. It is the seventh-largest country by area, the secondmost populous country (with over 1.2 billion people), and the most populous democracy in the world. A country of myriad subcultures which constitutes a unique phenomenon of 'unity in diversity'. India is the home of people of various ethnicity, religion, culture and languages. It has its own primitive cultures. Later, in different times this country was attacked by Greek, Shak, Hun, Pathan, Mughal, British, Dutch, French etc. So there is a diverse collection of culture and ethnicity, rather a conglomeration of these. The number of 100 -year-olds in India has steadily increased over the last few decades. Keeping the above background in mind, the present scenario-the prospects, expectations and problems faced by a large number of centenarians scattered in different regions of this country, has discussed in this review.
\end{abstract}

Keywords: Republic of India, Unity in diversity, Cultures, Present scenario, Centenarians

\section{INTRODUCTION}

\section{History}

The earliest authenticated human remains in South Asia date to about 30,000 years ago. ${ }^{1}$ With the progress of time gradually the Indus Valley Civilization developed, the first urban culture in South Asia, which was flourished during 2500-1900 BCE in present Pakistan and western India., ${ }^{2,3}$ During the period 2000-500 BCE, The Vedas, the oldest scriptures associated with Hinduism, were composed and historians have analyzed that the development of a Vedic culture in the Punjab region and the upper Gangetic Plain took place. ${ }^{3}$ Some historians also consider this period to have encompassed several waves of Indo-Aryan migration into this country. ${ }^{2}$ The caste system arose during this period, creating a hierarchy of priests, warriors, traders, and lastly the indigenous peoples who were regarded as impure, and small tribal units gradually coalesced into them. ${ }^{3}$ After that, as a result of non-Vedic religious movements,
Jainism and Buddhism emerged as other main streams of religion.

Indigenous emperors like Mauryan, Gupta, Chalukya etc. ruled their territory in different time periods. Later on, this country was attacked by Roman emperor Alexander and in subsequent times by different Muslim emperors. In the early 16th century, northern India was mainly under Muslim rulers. ${ }^{4}$ By the middle of 18 th century, this country was under British rulers, first East India Company and then British government. India became independent in 1947. Since then India is passing through a phase of transition in almost all sectors.

\section{Geography}

India is the seventh-largest country by area. ${ }^{5}$ It has a variety of geographic locations, ranging from high mountains in north (The Himalayas), long coast-line in south and part of west and east. The Indian climate is strongly influenced by The Himalayas and The Thar 
Desert. There is tropical rain forest and savanna, as well as subtropical humid and also mountain climate. One region experiences world's highest rainfall, one region experiences hot desert climate while another region experiences profuse snowfall in winter. River flowing in this country (like The Ganges, Brahmaputra, Godavari etc.) having great impact on climate, as well as on biodiversity.

\section{Culture and tradition}

According to the great poet Rabindranath Tagore, India is a place of pilgrimage for nations to mingle in a confluence of humanity. As a federal union, it consists of 29 States and 7 Union Territories (UT). Each State and UT has one or more official languages, and the constitution of India recognizes 22 "scheduled languages". India has no national language. 6 Hindi, presently with the largest number of speakers in this country, is the official language of the government. ${ }^{7}$ English is used extensively in business and administration purposes and has gained the status of "subsidiary official language". 8

According to the census report 2011, the religion in India with the largest number of followers was Hinduism (79.8\% of the population), followed by Islam (14.23\%) and the remaining were Christianity $(2.30 \%)$, Sikhism $(1.72 \%)$, Buddhism $(0.70 \%)$, Jainism $(0.36 \%)$ and others $(0.9 \%){ }^{9}$ The Indian caste system influence much on the social stratification and many of the social restrictions found in this country. Family values are very much important in the Indian tradition and multi-generational joint families have been the norm in India, though nuclear families are becoming more common in urban areas, now-a-days. Another important segment in the life of Indian people is marriage, majority of Indians, till date, with their consent, have their marriages arranged by their parents or other elders in the family. ${ }^{10}$ Marriage is thought to be for life, ${ }^{10}$ and the divorce rate is extremely low, especially among the older generations.

Another important factor is gene. Gene differs in different ethnicity, which has a great role on Indian perspective. ${ }^{11}$ All these issues have a great significance while discussing current demography concerning growing elderly population, particularly centenarians of India.

\section{DEMOGRAPHY}

India is the world's second-most populous country, with $1,210,193,422$ residents reported in the 2011 provisional census report. ${ }^{12}$ Population estimated to be more than 1.3 billion by $2017 .{ }^{13}$ Though population ageing is a global phenomenon, but India is the home of 10.39 crore people ages 60 or older, which is $8.6 \%$ of total population. Among them 5.11 crore are male and 5.28 crore are female. ${ }^{12}$ According to the United Nations Population Division, the population of India, ages 60 and older is projected to climb from 8 percent in 2010 to 19 percent in $2050 .{ }^{14}$ In India, present Crude Birth Rate is 21.8 and Crude Death Rate is 7.1/ 1000 population, though both showing a decreasing trend since last few decades. ${ }^{12}$

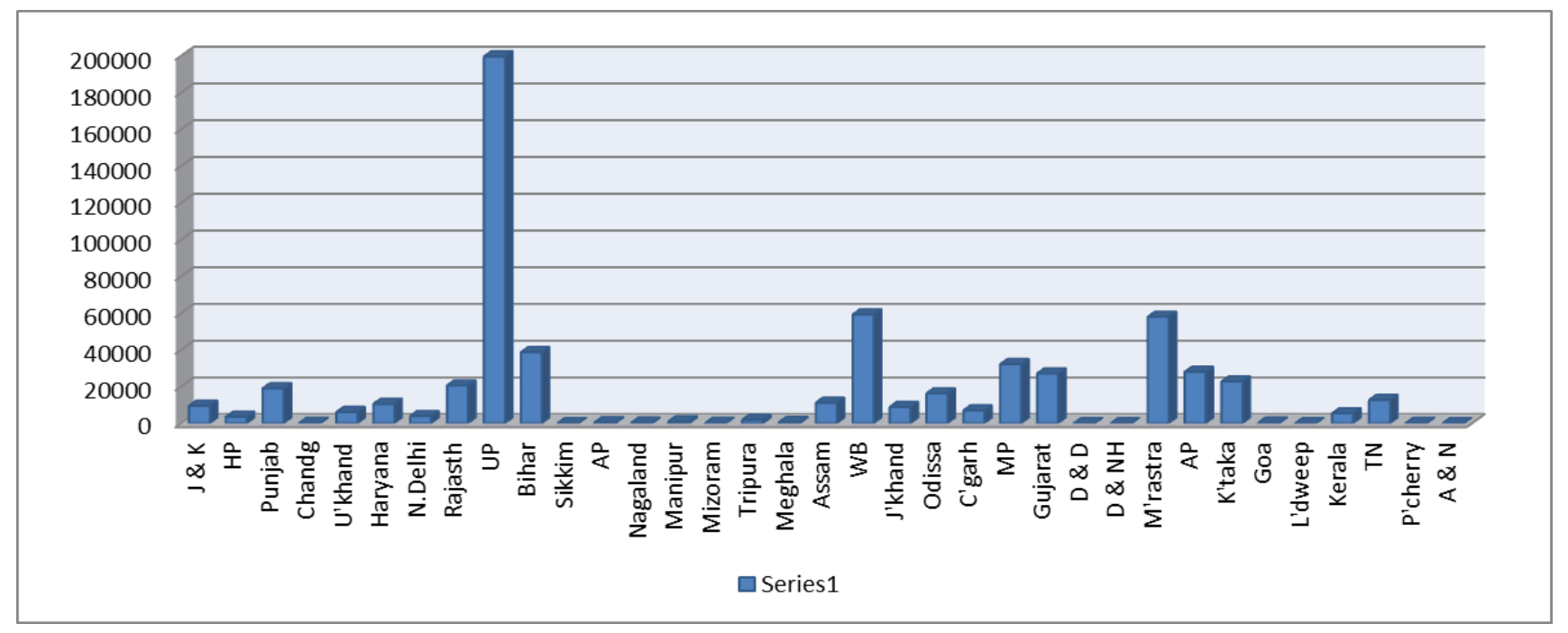

Figure 1: Geographical distribution of centenarians in India (census 2011).

But there is some controversy regarding the exact number of centenarians (aged 100 years or more) in this country. The Indian population census reported number of centenarians in 2011, is 605778, with slight female preponderance in number. ${ }^{15}$ Though the state Uttar Pradesh has the largest number of centenarians, almost 2 lakh or about a third of the national total, but centenarians are present in every States and UT (data presented in Figure 1). While the number of females is 3.16 lakhs, the males are 2.89 lakhs. Two-third of them live in rural and one-third in urban areas (presented in Figure 2). ${ }^{15}$ But, according to a report, world's centenarian population projected to grow eightfold by 2050 , from nearly 0.45 million (2015) to 3.7 million (2050), where the number of 
Indian centenarians mentioned 27000 (2015). ${ }^{16}$ Another landmark UN report on "ageing in the 21 st century", revealed India is at present (2012) home to between 11,000 and 20,000 centenarians. But this number is all set to rocket to anywhere between 1.51 lakh and 6.2 lakh. ${ }^{17}$ But these could be an under estimation of data. ${ }^{18}$ Regarding number of centenarians USA, Japan, China, India and Italy are in top five, where China and India are in the list mainly because of their large populations. Keeping track of one's exact age and birthdays is not considered an important issue in most parts of India, particularly in rural areas, obviously the age recorded for many in the above 80 age group would at best be a guesstimate, as many of them seem to prefer giving a round figure like 100 . Sometimes the age of the oldest child was thus used to estimate the age of the centenarians. ${ }^{19}$

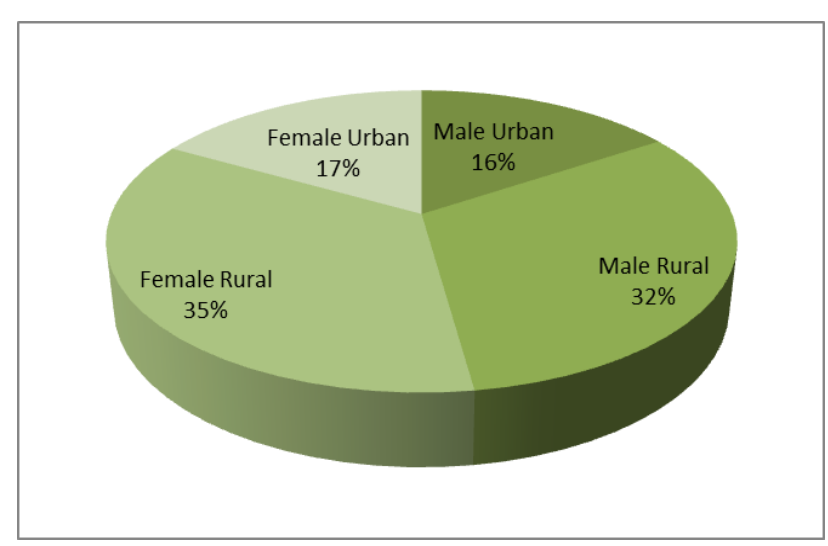

Figure 2: Rural-urban distribution of centenarians in India (data: census 2011)

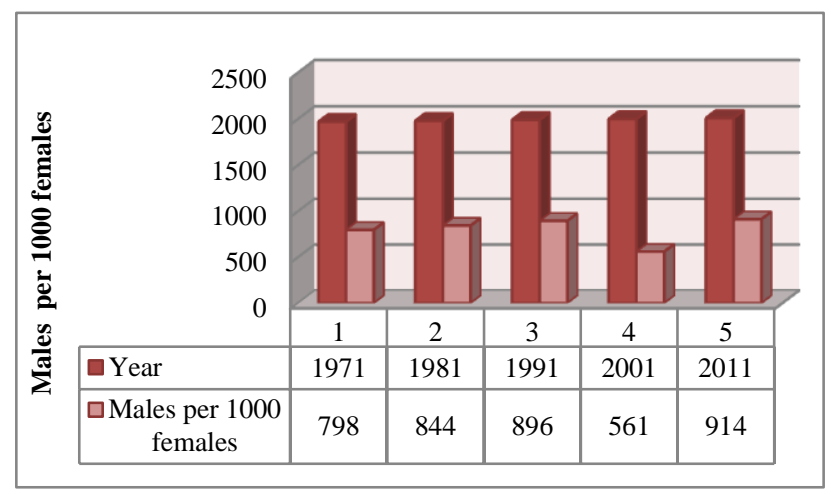

Figure 3: Sex distribution of centenarians in India (data: census 1971--2011).

Data source: estimated by author from past five censuses.

The human sex ratio, according to the 2011 census, is 940 females per 1,000 males. ${ }^{12}$ But this is reversed in case of centenarians of India (presented in Figure 3). Life expectancy in India is at 68 years, with life expectancy for women being 69.6 years and for men being $67.3 .^{20} \mathrm{~A}$ major concern relates to the increasing proportion of elderly women (centenarian also), especially widows in the population. Two reasons are given for the marked gender disparity in widowhood in India, firstly, longer life span of women compared to men and secondly, the general tendency for women to marry men older than themselves. $^{21}$

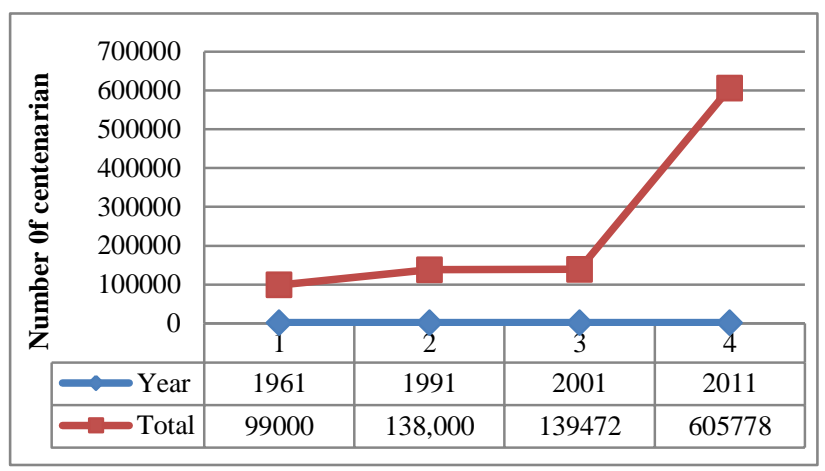

Figure 4: Number of centenarians in India.

Data source: compiled by author from-- 1. Ranjan Irudaya (2006), Population Aging and Health in India, Centre for Enquiry into Health and Allied Themes (CEHAT), Mumbai, p. 1, and 2. Census data 2001-11.

\section{Informal care giving}

Most of the centenarians need care and assistance from others. These support provided almost entirely by coresident family members (and sometimes neighbours), who are unpaid and not part of the formal health-care system. These caregivers may be of different ages (from teen to aged), different sex (male/female), having different relations with the diseased person (spouse, offspring, sibling, son/daughter-in-law or grandson/daughter), of different mentality (passion comes from love, responsibility, guilt or even greed), but in every case the responsibilities are more or less same. In India, though the illiteracy is high, but the works of these informal caregivers are comparatively easier from the perspective of the extended family (caregivers can work in a collaborative effort) and slower pace of life.

\section{Health and formal care giving}

Currently there are various health systems available in India, such as Allopath (most widely used at present), Ayurveda, Yoga, Siddha (all are ancient Indian culture), Unani (Arabic medical system introduced by Muslim rulers), Homeopathy (AYUSH), etc. But in any system health care for older adults was not categorized significantly and both physical and mental health care continued to be provided as for adults. ${ }^{22}$

Growing numbers of centenarians will put new and increasing demands on the health care system in India. There are around 50 physicians per 100,000 Indians, which are much less than the required number. This clearly indicates the deficiency status regarding the current issue. $^{23}$ Almost one-half (47 percent) of older Indians have at least one chronic disease such as asthma, angina, arthritis, depression, or diabetes. ${ }^{24}$ Recently a 
report from Indian Council of Medical Research (ICMR) reveals on the chronic morbidity profile in the elderly states that hearing impairment is the most common morbidity followed by visual impairment. ${ }^{25}$ At present, most of the geriatric Out Patient department (OPD) services are available at tertiary care hospitals. Therefore the only response to their emergency health problem seems to be hospitalization. But, since two-third of the centenarians resides in rural areas, it is mandatory that geriatric health care services be made a part of the primary health care services, but no significant improvement is visible in this sector till date.

\section{Economical background}

According to a report from World Bank in 2006, India contained the largest number of people living below the World Bank's international poverty line of US\$1.25 per day. ${ }^{26}$ India has the highest number of people living in conditions of slavery (18 million) and most of them are bonded labour. ${ }^{27}$ In this country both the extreme agegroups are neglected in present social structure. India has the largest number of child labours under the age of 14 in the world with an estimated 12.6 million children engaged in hazardous occupations. ${ }^{28}$ Older age-groups are neglected as same. In 2015, the Indian economy was the world's seventh largest by nominal GDP and third largest by purchasing power parity. ${ }^{6}$ Following marketbased economic reforms in 1991, India became one of the fastest-growing major economies, and is considered a newly industrialized country. ${ }^{29}$ Though agriculture is the mainstay of Indian economy, but industrialization and technological advancement (notably the information technology sector) also play a major role in current economic progress of this country. However, it continues to face the challenges of poverty, malnutrition and inadequate public healthcare. All these have a major impact in the life of centenarians. These elderly face a number of problems due to the absence of an assured income to support themselves for their healthcare and other social securities. At present, there are two kinds of pensions schemes available here, a lifetime monthly retirement benefit, mainly for government workers, and a lump-sum consolidated "provident funds" for some private sector retirees. But those who do not fall in either of these categories, there are national monthly old age pensions paid to the poor, widowed, or single elders aged more than 60 , lacking family support. But these are not significant and sufficient for their requirement.

\section{LIFESTYLE IN INDIAN CONCEPT}

In the post-vedic era, life of an average Indian was divided harmoniously into four stages (each called an 'ashram'), first, Brahmacharya (period of learning/studentship), second, Garhasthya (the period of family life), third, Banprastha (the period when one had to handover the household duties to one's successor and became free from family responsibility and luxuries) and lastly, Sanyas (the period when one had to lead a total secluded/ascetic life free of worldly things), and was meant to maintain the discipline, peace and harmony in the family and society. ${ }^{30}$ The last stage, 'sanyas' was meant for achieving the ultimate goal of mankind, i.e., 'moksha' through 'aatm gyan' (self-knowledge). For each period there were 25 years limitations. So it can be assumed that at that time there were many centenarians, who achieved up to that mark. In Rig Veda, desire for longevity and health (mental and eternal physical) is best exemplified in the much quoted Atharva Veda sukt: "Pashyem sharadah shatam, Jivet sharadah shatam" (let me see 100 autumns, let me live 100 autumns). ${ }^{31}$ In Yajur Veda, the Rishis seek blessings of the almighty to enable them to live for hundred years. This tradition is still very common when one elder person give blessings to a younger one. The entire literature considered details for male lifestyle only and it was assumed that a wife would follow her husband faithfully in his move through different stages.

The lifestyle has an impact on longevity and health in old age, this often the results from faulty lifestyle like addiction (smoking and alcohol intake), improper diet and lack of exercise as well as environmental and some other external factors. The 'Atharva Veda', believed that mental illness might result from divine curses and it also provides the description for mental illness like schizophrenia. In "Ayurveda", Shushruta advocates for 'swasthya vritta' (positive health) recommending 'dincharya' (daily routine), 'ritucharya' (seasonal routine), diet, exercise and other conduct meant for positive heath. In "Upnishads" spiritual dimensions of personality are recommended. 'Buddhism' emphasized a well ordered life by taking a midway between selfindulgence and extreme simplicity. 'Jainism' favors for non-violence, vegetarianism, warmth and human sympathy. 'Christianity' talked a lot about individual living style, systems and ways of salvation. ${ }^{30}$ All of these lifestyle concepts are being followed by various communities to their way of life towards 100 years. In changing structures of socio-political power and patterns of religious belief, lifestyle of individuals gradually began to change. At one time the authority of head of the family (in most cases the father) was unquestionable, and even the elder brother was given as much respect as father. As the time progressed, with the advent of modern technologies, newer job openings were created, younger generation became educated and rushed for those jobs, with urbanization traditional family life scattered and lastly, the knowledge and learning (which was a monopoly for few older persons at a time) became common place, and the old persons had no such utility for younger generations.

\section{DISCUSSION}

Loss of a social role and recognition made the centenarians helpless. Some of them feel themselves practically a burden to their family members in present socio-economic structure. They found themselves very 
lonely from the surrounding world, due to reduction in their work efficiency, suffering from chronic diseases, memory loss, increasing number of nuclear family and as a consequence gradual communication problem with next generation. These centenarians having the opinion, "why god is so cruel, he is not taking me up". While on the other hand, some think themselves independent, and they believe in will power, "I want to live more years, so I self-control with....". Advancement in modern medicine is not the primary factor in the secret of long life. ${ }^{19} \mathrm{New}$ studies are showing that genes have a significant impact on longevity, few subjects can attain longevity because a lucky combination of polymorphisms which allow them to have an efficient metabolism or an efficient response to different stress. Most of the others can attain a similar result by targeting the same pathways with appropriate life style or interventions. ${ }^{32}$

In eastern cultures, elders and their practical wisdom are respected. Their life style is a mixture of hereditary influence of eastern culture, familial and spiritual beliefs, restricted dietary habits, socializing patterns, physical and mental exercise. The centenarians exhibit an aura of optimism in their daily life. ${ }^{19}$ Most of them are constantly involved in physical (like walking, gardening, or cooking) or mental activity (like reading and memorizing). They eat nutrient rich, low calorie diet regularly, but in small quantities. These centenarians believe in 'something beyond what we know'. They pray daily at regular times and believe in divinity. Meditation, yoga, and cold water bathing are part of their daily rituals. ${ }^{19}$ Till date, very few studies were carried out on Indian centenarians, one of them is 'Tirupati centenarian study'. Though it was based on centenarians of south India, revealed most of the centenarians are from middle income group families, physically slim and active for their ages, they did not suffer from any major diseases in the past (except visual and hearing impairments), they are largely self-dependent, most of them were female and widowed, coped with many setbacks in life and have good social relationship, a god-fearing and positive outlook. $^{33}$

A hearty laugh and a joyous lifestyle speeds up heart rate, tone up nervous system and improves circulation, which is very important for longevity. But this optimistic concept is not applicable to all centenarians live in this country. There are several factors playing in this regard, for this sometimes cause of their longevity remains a mystery. Those factors may be genetic, regional (location), religious, dietary, physical/mental activity related and level of resilience. In case where poverty reaches to its extreme or in severe climatic variation all these factors get overlapped. Inter-caste and inter-religion marriage is not uncommon today. For this reason, the discussion on centenarians of this country is different in many ways than that of other countries.

A basic issue for current and future Indian centenarians centers on government versus family responsibility for their support. India has a current trend toward nuclear families, instead of the traditional multigenerational family, so the approaches and planning should be motivated to that direction to help the centenarians to lead a healthy aging.

\section{Recent developments (in research, education, and training)}

Now in India the centenarians have drawn the attention of researchers. Unlike last couple of decades now scientists, geriatricians, social workers are showing more interests on centenarians. Thus the researches on this age group are going on from different perspectives. This output now falls into several major categories like medical/geriatric, biological, behavioral, and the social investigations. ${ }^{33}$

In contrast to the development of research, the development in gerontology education is not significant. The first graduate course in gerontology was introduced by the Department of Psychology, S.V. University, in 1976, as an applied branch of psychology at the master's and doctoral levels. Despite these initial developments, gerontology as a special course of study in higher education has grown very slowly. Currently there are no significant stand-alone gerontology courses taught in the country. Strategies for enhancing gerontology education programs include increased research funding; faculty development and continuing education of existing faculty; widespread professional education, training and certification; expanded graduate and undergraduate degree education; and practical education for elders and their families, especially those who live in rural areas. ${ }^{34}$

Different NGOs are working on elderly people, as well as on centenarians. The Alzheimer's and Related Disorders Society of India (ARDSI), Centre for Gerontological Studies in Trivandrum, Calcutta Metropolitan Institute of Gerontology (CMIG) in Kolkata, The Heritage Hospitals and Foundation at Hyderabad, International Longevity Center at Pune are few names. They mainly provide research, training, and care services. There are also a large number of local NGOs serve elders by organizing programs on their rights, health care, and legal aid. ${ }^{35}$

\section{CONCLUSION}

Globalization has great impact in today's lifestyle, anything which was remote few years back is no more remote today. Food habit, addiction, caregiving, mental stability, mental stress, level of resilience everything is affected by globalization. So one day this planet will have record number of centenarians, but there will also be shortage of resources, and will be struggle for existence (according to Darwinism), and for natural biology younger people will survive and number of centenarians will decrease dramatically. But we should not take such pessimistic outlook on life at least at present; rather we should think how to protect centenarians and their wisdom in near future. Alternatively, we may speculate 
that future older adults are healthier and more active, and perhaps they could help (social involvement) create resources for those who need them (at any age). The path of sustainable lifestyle shown by them may influence our own lives.

The most pressing global challenges to older persons' welfare are poverty, malnutrition, unattended chronic disease, lack of access to safe drinking water and sanitation, and income security. ${ }^{36}$ This country is also facing these problems. Government has a major role to play in this situation. They should implement some policies and programs focusing the centenarians. The Government of India incorporated an act for the care and protection of the older adults by their children - 'The Maintenance and Welfare of Parents and Senior Citizen Act, 2007'. But they should spread more awareness by advertisement and campaigns with collaboration with NGOs, to take effective measure to train more professionals in this field and lastly to counsel and support the families having centenarians. We should respect the centenarians and their moral values, their wisdom and caregiving to these people should be an equal responsibility for individual, family, society and the government.

Funding: No funding sources

Conflict of interest: None declared

Ethical approval: Not required

\section{REFERENCES}

1. Petraglia M, Allchin B. Human evolution and culture change in the Indian subcontinent. In: Petraglia M, Allchin B, eds. The Evolution and History of Human Populations in South Asia: Interdisciplinary Studies in Archaeology, Biological Anthropology, Linguistics and Genetics; Springer; 2007: 6 .

2. Kulke H, Rothermund D. A History of India, 4th Ed, Routledge; 2004: 21-23.

3. Singh U. A History of Ancient and Medieval India: From the Stone Age to the 12th Century, Delhi: Longman; 2009: 186-187.

4. Robb P. A History of India, London: Palgrave; 2001: 80 .

5. Area and Population. Government of India. Archived from the original on 26 December 2007. Available at: https://india.gov.in/india-glance/ profile. Accessed on 4 April 2017.

6. Dharwadker A. Representing India's Pasts: Time, Culture, and Problems of Performance Historiography. In: Canning CM, Postlewait T, eds. Representing the Past: Essays in Performance Historiography; University of Iowa Press; 2010: 168-194.

7. Ottenheimer HJ. The Anthropology of Language: An Introduction to Linguistic Anthropology. Cengage; 2008: 303.
8. Ministry of Home Affairs, Government of India, Notification No. 2/8/60-O.L, 27 April 1960, archived from the original on 1 October 2014, retrieved 13 May 2011. Available at: http://www.rajbhasha.nic.in. Accessed on 7 March 2017.

9. C -1 Population by religious community -2011 . Census of India, (2011). Office of the registrar general and census commissioner, India. Ministry of Home Affairs, Government of India. Retrieved 25 2015. Available at: http://www.censusindia.gov.in/ 2011census/population_enumeration.aspx. Accessed on 12 March 2017.

10. Medora N. Mate Selection in Contemporary India: Love Marriages versus Arranged Marriages. In: Hamon RR, Ingoldsby BB, eds. Mate Selection Across Cultures, SAGE; 2003: 209-230.

11. Jorde LB, Wooding SP. Genetic variation, classification and 'race'. Nature Genetics. 2004,36:S28-S33.

12. Provisional Population Totals, Paper 1 - Census 2011, Office of the Registrar General and Census Commissioner, 2011, lay summary. Ministry of Home Affairs, Government of India. Available at: http://www.censusindia.gov.in/2011census/populati on_enumeration.aspx. Accessed on 17 March 2017.

13. Total Population - Both Sexes. World Population Prospects, the 2015 Revision. United Nations Department of Economic and Social Affairs, Population Division, Population Estimates and Projections Section. July 2015. Available at: https://readtiger.com/wkp/en/List_of_countries_by_ population_(United_Nations). Accessed on 10 March 2017.

14. United Nations Population Division (UN), World Population Prospects: The 2010 Revision (New York: United Nations, 2011). Available at: http://esa.un.org/unpd/wpp/index.htm. Accessed on 1 March 2017.

15. Registrar General of India (2011). Census of India 2011. New Delhi, India: Registrar General of Census Operations, Government of India. Available at: http://www.censusindia.gov.in/2011census/ population_enumeration.aspx. Accessed on 12 March 2017.

16. PEW: World's centenarian population projected to grow eightfold by 2050. Available at: http://pewrsr.ch/22PVly7. Accessed on 21 March 2017.

17. India to pip China in centenarians' count, UN report says. Times of India. Kounteya Sinha | TNN | Oct 1, 2012. Available at: http://timesofindia.indiatimes .com/india/India-to-pip-China-in-centenarianscount-UN-report-says/articleshow/16619507.cms. Accessed on 23 March 2017.

18. Registrar General of India. Census of India 2011. New Delhi, India: Registrar General of Census Operations, Government of India. Available at: http://www.censusindia.gov.in/2011census/populati on_enumeration.aspx. Accessed on 18 March 2017. 
19. Nair M. Field Studies on Centenarian Experiences in South Asia. Asian J Gerontol Geriatr. 2012;7:64.

20. Ram P. Life in India. Great Britain: Anvi; 2014: 12.

21. Leela G, Rajan IS. The Added Years: Elderly in India and Kerala. Economic and Political Weekly; 1999;34(44):WS-46-51.

22. Tiwari SC, Pandey NM. Status and requirements of geriatric mental health services in India: An evidence-based commentary. Indian J Psychiatry. 2012;54:8-14.

23. Dev SM, Rao NC. India: Perspectives on Equitable Development. Academic Foundation, 2009.

24. Chatterji S, Kowal P, Mathers C, Naidoo N, Verdes E, Smith JP, et al. The Health of Aging Populations in China and India. Health affairs (Project Hope). 2008;27(4):1052-63.

25. Shah B, Prabhakar AK. Chronic morbidity profile among elderly. Indian J Med Res. 1997;106:265-72.

26. World Bank. 2006. India - Inclusive growth and service delivery: building on India's success development policy review. Washington, DC: World Bank. Available at: http://documents.worldbank.org/curated/en/1789914 68268838564/India-Inclusive-growth-and-servicedelivery-building-on-Indias-success-developmentpolicy-review. Accessed on 1 March 2017.

27. The New York Times. "Modern slavery estimated to trap 45 million people worldwide".nytimes.com. 31 May 2016. Available at: https://www.nytimes. com/2016/06/01/world/asia/global-slaveryindex.html. Accessed on 1 March 2017.

28. Herath G, Sharma K. Child Labour in South Asia. Burlington: Ashgate publishing company. 2007: 100.
29. Nayak PB, Goldar B, Agrawal P. India's Economy and Growth: Essays in Honour of V.K.R.V. Rao, SAGE; 2010: xvii-xxxi.

30. Tiwari SC, Pandey NM. The Indian concepts of lifestyle and mental health in old age. Indian $\mathrm{J}$ Psychiatry. 2013;55 Suppl S2:288-92.

31. Griffith RT. Chapter 36 Hymn 21 in the Textbook of White Yajurveda. 1899: 292.

32. Passarino G, Francesco DR, Montesanto A. Human longevity: Genetics or Lifestyle? It takes two to tango. Immunity and Ageing. 2016;13:12.

33. Ramamurti PV, Jamuna D. Geropsychology in India. In: Misra G, eds. Psychology in India Volume 3: Clinical and health psychology. New Delhi, India, Pearson; 2010: 185-253

34. Liebig PS, Kunkel S. The global age quake and strategies to enhance gerontological education. In: Jamuna D, Kalavar JM, Khan AM, Liebig PS, eds. Global ageing: Care concerns and special perspectives. New Delhi, India: Kanishka Publishers; 2014: 245-258.

35. Panruti RV, Liebig PS, Duvvuru J. Gerontology in India; Gerontologist. 2015;55(6):894-900.

36. International Association of Gerontology and Geriatrics. (2014, March). Report. Seoul, Korea: International Association of Gerontology and Geriatrics-IAGG.

Cite this article as: Bhattacharyya KK. Centenarians in India: the present scenario. Int J Community Med Public Health 2017;4:2219-25. 